Peer review: This article has been subject to a double blind peer review process

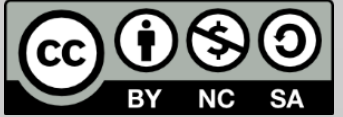

(C) Copyright: The Authors. This article is issued under the terms of the Creative Commons Attribution NonCommercial Share Alike License, which permits use and redistribution of the work provided that the original author and source are credited, the work is not used for commercial purposes and that any derivative works are made available under the same license terms.

\section{'Speaking to Others' in Nancy Huston's The Goldberg Variations and Slow Emergencies}

\author{
Polly Galis*
}

French, School of Languages, Cultures and Societies, University of Leeds

*Correspondence: jl10p2g@leeds.ac.uk

\begin{abstract}
Nancy Huston has previously claimed that her lack of any clear-cut national identity, or of any strong affiliation to her original cultural heritage, enables her to take on multiple identities within her literature. Huston's claim, however, can be deemed problematic if it presupposes a right to speak on the behalf of minority or 'subaltern' figures. This is particularly problematic in view of Huston's position as a white middle-class writer. In other words, the representation of others in literature can entail imperial repercussions. I will begin this article by postulating that literature can constitute a means of representing ourselves as other, or others tout-court (in keeping with Huston's transnational approach to(self-)representation), before turning to the work of Gayatri Spivak to illustrate how literary representations of others can betray a neo-colonial or imperial character. I will then establish the ways in which Huston avoids an imperial representation of others in The Goldberg Variations and Slow Emergencies by speaking to rather than for others. This article will also explore how this process is underpinned by an intersectional reading of otherness, in keeping with the critical work of Kimberlé Crenshaw and Elisabeth Spelman, and reminiscent of Gilles Deleuze and Félix Guattari's concept of 'becoming-minoritarian' and Rosi Braidotti's of 'becoming-woman' which, in the case of Huston's literature, are key to distinguishing between minority and 'subaltern' figures. In both cases, I will demonstrate how Huston speaks to not for others in both of the studied novels, and how, in so doing, she challenges monolithic and binary categories of being.
\end{abstract}

Keywords: speaking to/for, other(s), minority, subaltern, imperial, intersectional

As a Canadian born author who has lived in Paris for the majority of her life and who writes in English and French, Huston is no stranger to otherness, being a transnational other herself, and her literature reflects 
a need to give a voice to the other within the nation-state. This article will examine how Huston achieves this in The Goldberg Variations and Slow Emergencies. I will explore how, in both of these novels, Huston opts for a singular national setting - France - so as to deflect monolithic or binary definitions of national identity and to re-evaluate the plural composition of the nation-state itself and the citizens therein. The first point of discussion will be the notion that literature specifically enables a representation of others. I will then explore how these concepts are portrayed through a splitting of the narrative 'I' in The Goldberg Variations. The focus here will centre on minority figures specifically and the overlaps between different modes of oppression, and I will look to the feminist theory of Elizabeth Spelman. My secondary objectives will be to examine the representation of minority and 'subaltern' figures in The Goldberg Variations and Slow Emergencies, and how Huston's representation of otherness entails the process of 'becomingminoritarian' central to Gilles Deleuze and Félix Guattari's arguments. In so doing, I will be drawing upon the feminist theory of Rosi Braidotti on 'becoming-woman', and the intersectional theory of Kimberlé Crenshaw. More importantly, I will discuss the extent to which intersectional representation in The Goldberg Variations and Slow Emergencies enables a speaking to not for others, adhering to Gayatri Spivak's advice in An Aesthetic Education in the Era of Globalization and Can the Subaltern Speak?

At the outset, it should be noted that a transnational conception of literature and individual identity, whereby literature can be considered a means of representing ourselves as other than the dominant national subject, is necessary to those writers and citizens who cannot define themselves according to any one nation-state. Maryse Condé and Nancy Huston, most significantly, speak specifically of transnational subjects as those stuck between two places, between the here-and-now of a new home, and the there-and-then of a past one. As is the case with Huston, when the ties with new and old places are disappearing or were never there in the first place ('My original identity is weak and blurred' (Huston, 2007: 153), the possibility of writing identity from a non-national perspective becomes a question of categorical importance. It is necessary to imagine oneself as a global citizen, through literature, if one is deprived of a profound attachment to a national identity, so as to depict oneself as belonging in between these national spaces. As Diana Holmes suggests, 'intense imaginary experience of a world shaped by alternative narratives is essential if we are to see beyond the limits of the cognitive map into which we are born. We need stories' (Holmes, 2010: 88). Holmes explains that, for Huston, writing is a 'transitive verb', and her novels are about 'the world' in its entirety rather than a limited national 
space (Holmes, 2010: 87). In this way, literature can be understood to possess a 'transcendental value' which allows transnational subjects to express themselves in a way that is no longer mononational, and which allows native national subjects too to experience the otherness of other national imagineries (Le Bris, 2010: 15-16). Marjolaine Deschênes also concurs with this view, asserting that literature allows us to become aware of 'the alterity of others' (Deschênes, 2014). Literature therefore contains a transformative capacity to shape our understanding of the other spaces of the planet and the subjects located in them, and enables us to articulate our own hybrid identity, whether we be national or transnational subjects.

Mary Gallagher proposes a similar hypothesis, asking, 'Is the novel itself not engaged with inscribing or representing the plurality of virtual "I"s, which spill over the unique instance that is meant to be "me"?' (Gallagher, 2004: 27) The very process of novel writing, according to Gallagher, consists in expressing oneself as other(s). This is in keeping with Paul Ricœur's view that the space between 'mêmeté', corporal identity, and 'ipséité', personal identity, what makes us 'us', should be interpreted as 'ourselves as an-other'. This dialectical state of being can only be shown through literature, because literature itself is situated between rationality and irrationality, tracing a space between these two states that allows for nuanced dialectical outcomes to arise; something that is altogether other (Ricœur, 1990: 155). This should not be confused with a rejection of national identity altogether since multiple national identities can be considered as possible 'I's that make up the overarching ' $I$ '; each relevant to the single ' $\mathrm{l}$ ' but no longer the only relevant ' $I$ '. Literature is therefore the perfect mode of expression for (trans)national subjects who may struggle to make sense of their multiple (trans)national selves, and who may resent the imposition of mono- or duo-national labels. Literature allows the (trans)national writer to present her/himself as other(s).

The functionality of literature itself as that which allows for the representation of others is shown with particular clarity in The Goldberg Variations. The novel recounts stories about and characteristics of Lilianne, a middle-class musician, from the perspective of thirty narrative voices. As such, this novel is an apt example of representing oneself as other, since the novel itself is composed of multiple voices - of "others" and since the character of Lilianne takes on a different form depending on which narrative voice is speaking. Lilianne's identity is thus shown to be multi-faceted; to be composed of multiple other voices. Huston uses the metaphor of jazz and classical music to allude to her own literary technique as that which highlights the presence of transnational others within the nation-state. Miss Fournier, for example, says that, 'I said to 
myself that jazz, at least, was alive, a total freedom of expression, music outside of the law' (Huston, 2013: 86). In the same way that jazz is presented here as more liberating than classical music, so too is Huston's take on literature. She breaks the rules and in so doing is able to express herself in new and surprising ways. Marta Dvořák suggests this too, claiming that 'Nancy Huston always dared to transgress generic, linguistic and narrative borders. Even in her first novel, The Goldberg Variations, she said ' $I$ ' in the stead of thirty different people' (Dvorak, 2004: ix). Huston's fragmented narrative literary structure, like jazz, is 'outside of the law', and the act of splitting herself is proof of a 'total freedom of expression'. Huston subverts a traditional narrative framework by including thirty first-person narrative voices, who are all indirectly linked to the initial narrative voice of Lilianne, and who all live and work in France. The 'I' of the novel and the nation is split.

The interweaving of different narratives in The Goldberg Variations, and the way in which each voice sheds light upon the other voices challenges the need for an omniscient narrative ' $\mathrm{l}$ ', and forces the reader to perceive how the same person can enact different roles and personas depending on their given context. The way in which Huston achieves this is to represent the responses of the different narrative voices to Lilianne, the central narrative voice and fil conducteur of the novel. For Pierre, a friend of her lover's, who attends one of Lilianne's recitals, she was 'distracted, nervous' (Huston, 2013: 60), and for Christine, her close friend, Lilianne has been an ally against the rest of bourgeois society: 'Do you remember, Lili, how we used to say that those convinced were also vanquished on some level? That they had dominated and strangled all their doubts?' (Huston, 2013: 98-99) In both of these cases, Lilianne appears to be a shy and reserved individual, who fails to conform to a particular way of being or collective ideal, as those 'convinced' might do. From these perspectives, Lilianne sits on the periphery of bourgeois society. The Carpenter, on the other hand, a distant acquaintance of hers who meets her at her dinner party, has a paradoxical vision of Lilianne to Pierre and Christine. He is very critical of her bourgeois position, saying, 'You've got to have money to be skinny like the witch. Madam only eats caviar and smoked salmon, it makes sense...' (Huston, 2013: 79) The image of a nervous and anti-bourgeois individual is diametrically opposed to the stereotypical bourgeois woman alluded to in the Carpenter's comments, as is the pet name 'Lili' to the derisive terms 'Madam' and 'witch'. This juxtaposition demonstrates the extent to which our identity is informed by our context and the interpreting subject. In addition, the novel highlights the extent to which one changes over time, as seen when Christine says, 'But Lili: where are you? Will you leave me again, even lonelier than before? There are so few of us already, so very few' 
(Huston, 2013: 102). The implication here is that Lilianne has gone to the other side and embodied the bourgeois ideal. This is emphasized by an anonymous narrative voice, who adds that 'The amuses-bouches on the balcony, that's not you. The maid to welcome the guests, that's not you. The pearl necklace round the neck, that's not you' (Huston, 2013: 109). The impression which the Carpenter forms of Lilianne, according to this individual, is contrary to the "real" Lilianne. Yet, what the novel is challenging is the idea of a "real" essence which overrides all of our other selves. The representation of multiple Liliannes within the novel serves to negate the imposition of a single ' $\mathrm{l}$ '.

Though the narrative voices in The Goldberg Variations may be fictional characters, moreover, and hence retain a certain autonomy à l'écart of the author's own identity, the experiences of her characters are redolent of Huston's own experiences as a transnational subject. The attempt of individual characters to impose labels on Lilianne are similar to Huston's own experiences as a transnational writer. This is most clearly shown through the anonymous narrative voice, who says:

You are not Madame. Liliane. You're not even French, like your mother, nor Irish, like your father. You belong to no country, you belong to nothing. To no-one. To no cause. I have followed you for a very long time. You know that. You know that I'm the only one who loves you for who you really are (Huston, 2013: 109).

For the anonymous narrative voice, Lilianne is stateless and devoid of any sense of affiliation to any socio-political cause or class. She is not even a bourgeois 'Madame' as the world would have her be. The references to her statelessness here may be read as traces of Huston's own experiences of national loss. More importantly, the emphatic statement 'I' $m$ the only one who loves you for who you really are', takes on a dogmatic and threatening tone, emphasized by the anonymity of the voice in question. The anonymity, moreover, is juxtaposed with the personal quality of the message, especially one which claims to know the character better than anybody else. There is thus a negative portrayal of monolithic identity readings in play. The anonymous voice makes abstraction of the words so that one can draw a parallel between this narrative voice specific to the novel, and the nameless voices who impose labels on Huston and others of a transnational condition. In the same way that Huston can be at once connected and disconnected from her multiple national roots, as discussed in the introduction, so too can Lilianne be at once French and Irish, bourgeois and anti-bourgeois, shy and dominant. The parallels to be drawn between the two do not prove the novel to be an autobiographical text, but indicate how Huston's 
experience as a transnational other permeates her literature to suggest alternative ways of experiencing otherness.

It has to be noted, though, that this becomes problematic when the transnational writer's representation of her/himself as other takes the form of representing others tout court. One has only to think of Huston's declaration in 'Traduttore non è Traditore' that 'The weakness of my original roots, to which my chosen exile came to add itself, allows me to slip into the skin of everyone and anyone' (Huston, 2007: 153). If a transnational status allows for a less egocentric take on the world, Huston does not escape the inevitability of a middle-class, Western optic. Huston herself admits in 'Traduttore non è Traditore' that 'I was never oppressed as a Canadian nor as White nor as a little-bourgeoise nor as a renegade protestant' (Huston, 2007: 153). Her self-confessed position as a white, middle-class writer might be seen to render her representation of others problematic. Linda Martín Alcoff resumes this well in the following quotation: 'there has been a growing awareness that where one speaks from affects both the meaning and truth of what one says, and thus that one cannot assume an ability to transcend her location' (Alcoff, 2010: 1). One cannot escape the effect of national roots absolutely, even as a transnational author. This becomes dangerous when that which determines the speaking subject goes on to taint the representation of others in Western texts. As Alcoff substantiates:

in both the practice of speaking for as well as the practice of speaking about others, I am engaging in the act of representing the other's needs, goals, situation, and in fact, who they are, based on my own situated interpretation.

(Alcoff, 2010: 2)

Huston has to be wary of her Western subjectivity and its impact on her representation of others. The shift from representing oneself as other to representing others can give way to a dangerous appropriation of the other's voice.

However, the fear of entering neo-colonialist forms of discourse can be a threat to the possibility of Western responsibility. As Alcoff notes, 'The major problem with such a retreat is that it significantly undercuts the possibility of political effectivity' (Alcoff, 2010: 5). There is a need to undertake responsibility towards others, without forging a new identity for them based on our own experiences. Spivak, for one, suggests the possibility of a middle ground. Alcoff explains that 'In the end Spivak prefers a "speaking to", in which the intellectual neither abnegates his or her discursive role nor presumes an authenticity of the oppressed' (Alcoff, 2010: 5). Spivak suggests speaking to not for, so that a Western subjectivity is prevented from taking over the narratives of minority 
subjects absolutely. This indicates that there is a possibility of a transnational literature that avoids a neo-colonial approach. Indeed, Spivak agrees with the principle of literature as an aesthetic collective that transcends national borders, saying 'For me, the "philosophicoliterary" - the aesthetic in aesthetic education - is the means for persistently attempting collectivities to come' (Spivak, 2013: 464). From this standpoint, transnational literature should be a question of recognizing otherness whilst forging a discourse of sameness in the process; a process that might also be met by speaking to rather than for others, in order to avoid a rhetoric of sameness based on purely Western perspectives.

I would argue that Huston avoids speaking for minority figures by enabling them to speak to each other. The fragmented narrative structure of The Goldberg Variations not only enables us to perceive how a single ' $\mathrm{I}$ ' can have multiple facets, but also enables an interaction between different narrative spaces to the point that what matters most is what happens in-between them. This intra-narrative dialogue, moreover, highlights the different ways of experiencing otherness. The technique is initially alluded to at the beginning of The Goldberg Variations through a discussion between Bernard and the unnamed Carpenter: 'The Blacks perched on the steps outside their house were throwing us dirty looks. "It feels good to be the "other" for once, he said to me, just to get a sense of what the Arabs must feel like back home"' (Huston, 2013: 73) While the Laborer is part of a minority group as a working-class male, his position as a white male means that he cannot be considered altogether other. This is a direct parallel to Deleuze and Guattari's theory on the 'faciality machine' and the reconfiguration of 'White Man himself', which comes to present itself on a micro-level within social spheres (Deleuze and Guattari, 2013: 206 and 216). ${ }^{i}$ The 'Blacks' and the 'Arabs' on the other hand, are other to another degree. This is emphasized through the Laborer's reference to them as altogether '"other"'. This is closely reminiscent of what Elizabeth Spelman termed the 'ampersand problem', whereby different modes of oppression are layered on top of one another as though they affected people interchangeably. As Spelman argues in Inessential Woman: 'a Black woman cannot be "female, as opposed to being Black"; she is female and Black' (Spelman, 1988: 120). In this particular scenario one can see how this issue is not only specific to gender studies. Though the individual in question is male, he too falls victim to the 'ampersand problem' in being working-class and black. His status of otherness is twice removed from that of the norm of a white-dominated and socially hierarchical nation. In this way, it is clear that Huston is challenging limited categories of being. 
This complicates the issue of speaking to and for others somewhat. To speak as a black or working-class subject when one is a self-confessed white, middle-class writer, such as Huston, can take the form of speaking for them, which is always loaded with neo-colonial implications. To speak as a black working-class subject, then, is still more problematic . But the way in which Huston overcomes this difficulty is, firstly, to recognise her privileged status, as discussed earlier and as Spivak suggests a writer should do (Spivak, 1981), and secondly, to give equal representation and to grant equal importance to each voice. She posits the narrative voices in such a way so as to allow a dialogue to emerge, rather than a hierarchy. Fréderic Dumont, for instance, another character in the same text, is a black musician who expresses frustration at the French hexagon's hypocrisy in claiming his musical success for the nation in spite of national racism: 'They like that, the French. They're proud of me because I'm famous and French. It proves they're not racist. [...] Bullshit.' (Huston, 2013: 239) The meaning inherent to this quotation is twofold. First, to demonstrate that racism is still prevalent in France, thus alluding to the prevailing colonial or neo-colonial structures of present day France. Secondly, to stress yet again the different ways of experiencing otherness. More importantly, Huston explores how people can fit into several categories at the same time, and adopt a dominant or dominated position simultaneously. Dumont's position as a musician, or a musical intellectual, for instance, makes him the subject of criticism from Marie, who, according to her husband, 'doesn't like that, intellectuals [...] In her eyes, they're lazy, people who do virtually nothing, who don't know what it's like to work' (Huston, 2013: 79). A discourse of class interweaves with a racial one, thereby challenging Dumont's minority status and making us rethink Marie's own social position. Different forms of marginalization are not pitted against one another, but incorporated within the same narrative so as to highlight the overlaps between them. This allows for a speaking to rather than for others and, in the same move, negates a monolithic reading of the nation-state.

In turn, class issues are linked to those of gender too, as seen when the unnamed Laborer throws a plate of potatoes in his wife Marie's face, after she had just finished preparing them for him: 'The first time that Marie made me boiled potatoes, I threw the plate in her face. She understood straight away. I earn a living now, I'm done with boiled potatoes' (Huston, 2013: 79). Far from being angry with him, and drawing upon a rhetoric of gender inequality, Marie apologizes because she understands him ('She understood, she apologized' (Huston, 2013: 80). In this instance, issues of class override a discourse of gender inequality. There is an intersectional approach to feminism in play. Multiple marginalized voices are all arguably other in their own right. It is 
clear then, that this is not so much a question of Huston speaking for others, but of multiple voices speaking to each other, thanks to a dialogical narrative structure. If any one of these narrative voices or protagonists on their own were to be the sole narrative voice, the structural importance of each character would diminish; their position as one point of view amongst many others is only reflected through a dialogical process with other narrative voices. Like Bernard who 'didn't like heroes, leaders, "those who shout US so loudly that they silence all the Is"' (Huston, 2013: 74), Huston too distances her characters from singular, collective group identities, labels, and binary categories. The issue here, moreover, is that a direct solution is never given to the problem of identity. In fact, a solution might inadvertently be more detrimental than beneficial, imposing further categories within existing ones. On another note, to opt for a solution to the competing minority figures within this novel might be to impose a negative hierarchy, whilst there is no right or wrong in this novel, nor winner or loser. Each minority figure is given a chance to speak to another, without overriding any other. Just as no one reading of Lilianne or Huston's identity is the "real" one, no one category or label fits the other minority figures represented in this novel, and no one minority figure is shown to be more oppressed or more important than another.

If Huston allows the narrative voices to speak to one another, moreover, she is also aiming to enable a dialogue between the narrative and the reader. Once again, Huston draws our attention to this poioumenic process through the metaphor of jazz amongst other musical genres, this time referred to through the narrative voice of Manuel: 'music which is alive - nowadays jazz, blues, pop, rock and reggae - truly excites the desires of the masses while, through a dialectical movement, it is excited by them' (Huston, 2013: 226). Jazz, blues, pop, rock and reggae are representative of the masses because they originate from there. Furthermore, that which is key to our perception of jazz, blues, pop, rock and reggae as platforms for representing the other, is the 'dialectical movement', between the music and the people. This is exactly what Huston achieves through her literature; applying a dialectic specific to a musical genre to the process of writing instead. She is able to represent others in literature because her novel, by being composed of multiple narrative voices, and by being read by multiple readers, invites a dialectical relationship between the literary text and others, both within and outside of the novel. The process of voices speaking to each other becomes tripartite.

It is now important to distinguish between minority figures and 'subaltern' figures, since this is an essential addition to an intersectional discussion, and will enable us to establish the different forms of speaking 
to which occur in The Goldberg Variations and Slow Emergencies. At this point, our argument must come back to Spivak and her distinction between minority others and the subaltern 'quite-other'. If the 'other' refers to subjects who form part of a minority group, the subaltern subject constitutes the 'quite-other' who belongs to an even smaller minority, and who has, as Spivak asserts, 'limited or no access to the cultural imperialism' (Spivak, 1992: 45). The word subaltern was initially used by Gramsci to refer, as Celia Britton has summarized in more accessible terms, to the 'non-hegemonic subject' (Britton, 1999: 53). Contrary to what this implies, the subaltern is not absolutely analogous to a specific class, race or otherwise because, as Britton outlines, hegemony (against which the subaltern is set) for Gramsci 'is not correlated with any one particular class' (Britton, 1999: 53). The term subaltern or 'quite-other' can therefore be applied to any subject or voice that exists outside of a set hegemonic discourse, regardless of the subject or voice's class, race, gender and the like, as can the term other. The concept of subalternity, however, is nevertheless more paramount to the notion of 'speaking on behalf of', because the subaltern is prevented from contributing to hegemonic discourse, and is thus more prone to being spoken for than those minority subjects who, though other, are not distanced from hegemonic discourse to the same degree. While the minority position constitutes a condition of otherness in opposition to that of the dominant national Subject, or what Tamsin Lorraine terms 'an alternative epistemological claim to that of the dominant culture', the subaltern position is entirely detached from that 'dominant culture' (Lorraine, 2011: 71). One might be compelled to refer to others as oppressed, and 'quite-others' as absolutely oppressed. The issue of the speaking to not for others is thus rendered more complex by the issue of whom one is speaking to or for.

Notwithstanding this complication, it should be noted that, while the 'quite-other', or subaltern subject, complicates the issue of speaking to somewhat, the subaltern is not entirely voiceless as Spivak previously argued in 1988. Spivak changes her mind in 2013, explaining that:

I presented 'Can the Subaltern Speak?' as a paper twenty years ago. In that paper I suggested that the subaltern could not 'speak' because, in the absence of institutionally validated agency, there was no listening subject. My listening, separated by space and time, was perhaps an ethical impulse. But I am with Kant in thinking that such impulses do not lead to the political. There must be a presumed collectivity of listening and countersigning subjects and agents in the public sphere for the subaltern to 'speak'. (Spivak, 2013: 326) 
In other words, the subaltern can speak provided that there is a listening subject', who must be self-aware of where $s /$ he is listening from, in the same way that Huston and other transnational writers must be aware that they are writing from a privileged position. However, since these subaltern figures have no 'institutionally validated agency', it is difficult to see how they would be able to speak in a direct way, other than through silence, because they have no direct access to public discourse within a hegemonic or imperial narrative framework. The issue of speaking to not for comes to the fore again, but the means of enabling this has changed. It is not possible for subaltern figures to speak to each other as the minoritarian figures did in The Goldberg Variations, since they can only speak through silence, and one has to be even more careful to ensure that their silence is not filled in via the writer's narrative intervention.

It is henceforth much more difficult to discern subaltern discourse because the only subaltern speech which comes to be felt, in The Goldberg Variations at least, is through what is not said. There is a parallel to be drawn between Marie's silence about the boiled potatoes which I discussed earlier on, and the self-immolation of sati women which Spivak speaks of, when she refers to the broader socio-political implications of saving them, owing to how 'white men are saving brown women from brown men' (Spivak, 1993: 93). Though saving them would be, on some level, a moral act, to do so would also be to entrench them in further oppression rather than leading them to emancipation.

Similarly, Marie explains that she is able to accept her husband's act of throwing potatoes on her, despite the obvious status of oppression that this implies. If Huston were to save her, it would be a matter of a middleclass woman saving a working-class woman from a working-class male. Marie cannot speak as a subaltern figure, but rather than speaking for her Huston invites the reader to listen to her and to interpret her silence in such a way as to understand her position without it being articulated directly. However, it is difficult to determine just how far Marie is truly subaltern. After all, she still remains a white female within a predominantly white society. As such, she does not constitute 'radical alterity' itself which Spivak considers to be essential to being a subaltern figure (Spivak, 2013: 97). Perhaps then, the truly subaltern figures in The Goldberg Variations are those who are not given a narrative voice at all, such as the maid who works for Lilianne, whom the Labourer refers to in the following way: 'I saw the maid when we arrived. She wasn't allowed to listen to the music, of course. Were there not enough chairs?'

(Huston, 2013: 79) In the same way that the maid is not allowed to listen to the music, she is not included within the composite narrative ' $I$ ' of the novel. She resides on the margins of the narrative as a subaltern figure 
does in an imperial setting such as that of France, which I referred to earlier in this article in relation to Fréderic Dumont. Beyond even that, the absence of narrative voices in a similar position to this unnamed maid highlights the extent of subaltern subordination, and their absence from the novel reminds us of their absence within hegemonic and imperial settings in general. The subalterns in this novel are only able to speak through their absence.

In Slow Emergencies too, the extremity of the subaltern position only comes to be felt through its juxtaposition with that of the minority position. It is only in Slow Emergencies that the subaltern 'quite-other' is able 'to speak' through silence, since they are key narrative figures who work in opposition to key minority ones. This novel like The Goldberg Variations underscores the divisions and subdivisions within the nationstate of France. The novel tells the story of Lin, a French dancer who is oppressed by her role as mother and wife in a bourgeois setting. Her roles limit her choice and level of employment, and sap her of her vital energy, since she becomes a source of support within the family nucleus rather than an emancipated subject. In order to free herself she chooses to flee this family unit. However, in so doing, the care of Lin's children is left to subaltern women, whose story is not told. Huston thus sets up a comparative framework which questions the exclusions of Western feminism and national discourse. This is clearly shown through the concept of 'becoming-woman' in operation throughout this novel. The notion of constant anti-genealogical becoming is the core premise of Huston's Slow Emergencies. In fact, the conceptualization of becoming is emphasized in this novel purely because the minoritarian protagonist is female. Her escape from a minoritarian status, or what Deleuze and Guattari name a 'line of flight', is thus clearly illustrative of the process of becoming which, according to Deleuze and Guattari, is innately gendered in its foundations (Deleuze and Guattari, 2013: 63).

In order to show this, one must first outline what is meant by a 'line of flight'. According to Deleuze and Guattari, 'a line of flight must be preserved to enable the animal to regain its associated milieu when danger appears' (Deleuze and Guattari, 2013: 63, emphasis in original). A line of flight enables the minoritarian subject to forge an escape route away from the minoritarian position when all else fails. This line of flight is thus key to the process of 'becoming-minoritarian', since it constitutes the gateway by which the process can take place. In turn, the process of 'becoming-minoritarian' is innately gendered because, as Deleuze and Guattari point out:

All becoming is minoritarian. Women, regardless of their numbers, are a minority, definable as a state or subset; but they create only by making 
possible a becoming over which they do not have ownership, into which they themselves must enter; this is a becoming-woman affecting all of humankind, men and women both (Deleuze and Guattari, 2013: 123).

Since 'All becoming is minoritarian', and since women are the example par excellence of the minority subject, the concept of 'becoming-woman' is a term which can be applied universally to any entity or identity which enacts a process of 'becoming-minoritarian' as a form of emancipation from a minority status. The end product of becoming is not implied within the notion of becoming itself. The only key denominator is that they all stem from an initial minority position which that subject can either adopt or reject, through a process of deterritorialization; a line of flight. By 'becoming-woman', moreover, it should be understood that 'woman' is not meant in a literal way, but as the refusal to become what man has made of woman. As Braidotti explains, 'Becoming-woman entails actualizing the event of "woman" in a way that allows one to deterriorialize from conventional points of reference in being-a-subject' (Braidotti, 1994: 112). 'Becoming-woman' then, for Braidotti, necessitates a deterritorialization from what it means to be a female subject according to 'conventional points' established, one might argue, by a patriarchal society.

In Slow Emergencies, Huston is directly challenging the 'conventional points' of woman and motherhood. The novel takes the form of a bildungsroman, and the key protagonist Lin's shift from her role as mother to that of a liberated dancer is the primary marker of this process of 'becoming-woman' central to the novel. Lin chooses to abandon her children because, as she puts it, 'I need to dance...' (Huston, 1994: 110) In raising children, Lin has to sacrifice her career and her autonomy in order to invest herself in her children (Huston, 1994: 60). The act of abandoning her children is for Lin a line of flight by which she can enter a process of 'becoming-woman'.

There is an indication, however, that some subjects cannot access a line of flight, that it is reserved for the privileged few. One has only to think of Theresa the maid in Slow Emergencies. While Lin leaves home and reterritorializes in dance, Theresa is forced to return to Lin's home to take on her domestic duties again in Lin's stead, allowing Derek some peace of mind in her absence. As the narrative voice of Derek explains:

He knows that when he gets home tomorrow, Theresa will understand everything just by looking at him, that she won't ask him any questions, and that she'll take off her shoes and put on her slippers on and calmly go and fetch the hoover, from where she left it several years earlier (Huston, 1994: 110). 
The fact that Theresa asks no questions and continues with the same work from years before, demarcates her position as a passive object within the novel, whose own process of 'becoming-subject' is neglected as is, by extension, her potential for 'becoming-woman'. In this instance, there is a clear division between minoritarian categories, into which Lin falls, and that of the subaltern, which applies to Theresa. It is even more shocking that Lin's line of flight and Derek's peace of mind is reliant on Theresa remaining in a subaltern position. The fact that Theresa resides on the margins of the novel serves as an accurate metaphor of her position as a subaltern woman in a white, European society. It is also no coincidence that, at the end of the novel, when Lin is surveilling the world beneath her window as a free woman, that she spots 'A Black childminder pushing a white baby's pram' (Huston, 1994: 190). The narrative voice of Lin's response to the view is that 'All of this is mine' (Huston, 1994: 190). The omniscient narrative voice is thus alluding to the colonisation of the subaltern at work in Western society. To come back to the faciality machine, Lin is representative not of women as such, but of 'White Man himself', and her line of flight is shown to be a privilege reserved for a few. Lin's decision to abandon her children to become-woman is only possible because a subaltern woman will push her pram for her.

This is reminiscent of Kimberlé Crenshaw's intimation that white women's attempts at emancipation can inadvertently oppress women of colour, when she asserts that the 'failure of feminism to interrogate race means that feminism's resistance strategies will often replicate and reinforce the subordination of people of color' (Crenshaw, 2003: 178). A discourse of race comes to intersect with that of gender, and the desire to become-woman is no longer only about female emancipation but a call to black female emancipation too, and, more deeply still, a call for the recognition of further binaries at work within the male-female dialectic. This is an apt answer to Crenshaw's controversial view that the 'problem with identity politics is not that it fails to transcend difference, as some critics charge, but rather the opposite - that it frequently conflates or ignores intragroup differences [...] such as race and class' (Crenshaw, 2003: 175). It is worth recalling Crenshaw's belief that, as it stood in the late twentieth century when, notably, Huston's Slow Emergencies was published, feminism had not gone far enough in this regard: 'Although racism and sexism readily intersect in the lives of real people, they seldom do in feminist and antiracist practices' (Crenshaw, 2003: 175). As third-wave feminism moves towards a fourth-wave, there are signs of a more intersectional approach emerging, moving towards what Sariya Contractor names a 'space of solidarity' (Contractor, 2012: 144). Although, as Contractor also points out, there are still too many 
lacunae in theory, and the fourth-wave remains too vague a project as of yet to label it a benchmark of intersectionality. That aside, to apply this view to feminist theory is to request a revisiting of racial and class difference amongst women themselves, so as to see how forms of injustice differ for different women. By extension, one should ask whether Huston does not adopt the role of Lin herself in Slow Emergencies as a white woman stealing a subaltern narrative. Huston herself possesses a transnational, nomadic identity, reterritorializing herself in writing one might argue, and it is possible to argue that she has silenced the voices of other, subaltern women. The lacunae in the novel, however, Theresa's silences within the narrative, enable Huston to iterate the suffering of marginalized women like Theresa, without speaking for her. The gaps in the narrative make us as the reader question whether her/his nomadic consciousness can take place, if at all, and enables subaltern figures to speak through silence, and Huston is inviting her readers to listen more attentively.

It is clear, then, that in both The Goldberg Variations and Slow Emergencies, Huston is able to blur the boundaries between such categories of being as class, race and gender, thus opting for an intersectional approach to reading identity. However, Huston does not deny her position as a middle-class, privileged writer, in spite of her transnational and female status, and tries to avoid the imperial speaking for that Spivak condemns. Although this is arguably impossible, Huston goes a long way towards achieving a non-imperial representation of others through her literary techniques. In The Goldberg Variations, the fragmented narrative structure allows for multiple narrative 'I's to emerge, which all make up essential parts of the overarching narrative voice, enabling a dialogue to emerge between different minority figures. This dialogue challenges monolithic definitions of what it means to belong to a minority group and to the nation-state in a wider sense, and overrides the threat of speaking for minority groups since they are, instead, speaking to each other. In Slow Emergencies, Huston uses ellipsis and structural juxtaposition in order to highlight different modes of female oppression and to outline the limits of 'becoming-woman'. In so doing, Huston is once again blurring the lines between categories of being, and enabling subaltern figures to speak through silence. Huston thus achieves the same goal in both novels through different means. In both novels Huston avoids speaking for minority and subaltern subjects, and answers the 'ampersand problem' to some degree by destabilizing singular and binary categories of being, and by offering a more intersectional view of identity and otherness. 


\footnotetext{
' Key traits of normative figures come to be distorted ('faciality machine') so as to reflect a wider meaning and to support broader hegemonic structures ('White Man himself'). For example, a white middle-class female or a working-class male could both come to stand in for 'White Man himself', even though neither embodies all of the characteristics of this overriding symbol (white, male, middle-class). In this scene, then, though the Laborer is working-class, his position as a white male allows him to stand in for the wider signified of 'White Man himself'.
}

\section{References}

Alcoff, L. M. (2010), 'The Problem of Speaking for Others', http://www.alcoff.com/content/speaothers.html, accessed 30 January 2015

Braidotti, R. (1994), Nomadic Subjects, New York: Columbia University Press

Britton, C. M. (1999)., Edouard Glissant and Postcolonial Theory: Strategies of Language and Resistance, Charlottesville: University Press of Virginia

Contractor, S. (2012), Muslim Women in Britain: De-mystifying the Muslimah, Abingdon: Routledge

Crenshaw, K. (2003),'Mapping the Margins: Intersectionality, Identity Politics, and Violence Against Women of Colour', in Alcoff, L. M. and Mendieta, E. (ed.), Identities: Race, Class, Gender, and Nationality, Oxford: Blackwell, pp. 175-00

De Kock, L. (1992), 'Interview with Gayatri Chakravorty Spivak: New Nation Writers Conference in South Africa', ARIEL: A Review of International English Literature, 23 (3), http://ariel.synergiesprairies.ca/ariel/index.php/ariel/article/viewFile/25

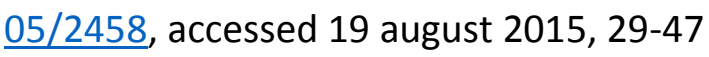

Deleuze, G. and Guattari, F. (2013), A Thousand Plateaus, London: Bloomsbury

Deschênes, M. (2013), 'Penser la Création Littéraire avec Paul Ricœur', Fabula: La Recherche en Littérature, 1, http://www.fabula.org/colloques/document1907.php, accessed 16 November 2014

Dvořák, M. and Koustas, J. (ed.) (2004), Vision/Division: L'œuvre de Nancy Huston, Ottawa: University of Ottawa Press 
Holmes, D. (2010), 'To Write is a Transitive Verb: Nancy Huston and the Ethics of the Novel', Contemporary French and Francophone Studies, 14 (1), 85-92

Huston, N. (1994), La Virevolte, Paris: Actes Sud

Huston, N. (2013), Les Variations Goldberg, Arles: Actes Sud

Huston, N. (2007), 'Traduttore non è Traditore', in Le Bris, M. And Rouaud, J. (ed.), Pour une Littérature-Monde, Paris : Gallimard, pp. 151160

Le Bris, M. (2010), 'Lisez Rimbaud!', in Le Bris, M. and Rouaud, J. (ed.), Je est un Autre: Pour une Identité-Monde, Paris: Gallimard, pp. 11-27

Lorraine, T. (2011), Deleuze and Guattari's Immanent Ethics: Theory, Subjectivity, and Duration, New York: SUNY Press

Ricœur, P. (1990), Soi-Même Comme un Autre, Paris: Éditions du Seuil

Spelman, E. (1988), Inessential Woman: Problems of Exclusion in Feminist Thought, London: The Women's Press

Spivak, G. C. (2013), An Aesthetic Education in the Era of Globalization, Cambridge: Harvard University Press

Spivak, G. C. (1993), 'Can the Subaltern Speak?', in Williams, P. and Chrisman, L. (ed.), Colonial Discourse and Post-Colonial Theory: A Reader, Hemel Hempstead: Harvester

Spivak, G. C. (1981), 'French Feminism in an International Frame', Yale French Studies, 62, http://www.jstor.org/stable/2929898, accessed 14 september 2015, 154-184

\section{To cite this article:}

Galis, P. (2016). 'Speaking to Others' in Nancy Huston's The Goldberg Variations and Slow Emergencies. Exchanges: The Warwick Research Journal, 3(2), 199-215. Retrieved from:

http://exchanges.warwick.ac.uk/index.php/exchanges/article/view/98 